\section{Oncology sleep}

$\mathrm{D}$ r. $\mathrm{M}$ is a medical oncologist. He's the kind of oncologist who blends encyclopedic knowledge of transcription factors with the writing of scholarly articles about the nature of hope. He's the kind of oncologist who touches a woman's knee when she starts to cry and it doesn't feel forced. He's the kind of oncologist who, with an impish smile, corrects his residents to say, "She's a woman with adenocarcinoma," and not "She's an adenocarcinoma." He's the kind of oncologist who tries to pay back the stories patients tell him with stories from his own life, about his wife, his daughter, his father, his house and his cello. He's the kind of oncologist who has a hundred different ways to tell someone they will die soon depending on the way they want to hear it.

$$
* * *
$$

Sid wants to make it to the spring so he can ride his motorcycle. Three or four months, that's all. Though Sid looks healthy and huge, Dr. M's declaration to me, outside the room, that he likely has two months left to live weighs down Sid's words as soon as he releases them. It seems so simple a request.

Despite his orange t-shirt and black leather vest, he's brought his mother to his appointment. They look close in age. She is cheery, and I like them both. Dr. M starts to talk specifics (new aspartate aminotransferase elevation despite last-option chemo), but Sid and his mother are talking in non sequiturs about the walks they've started taking again and the fatigue he's feeling.

"This whole body is mine," he seems to be saying. "Don't break it into little pieces."

I can feel them pressing Dr. $\mathrm{M}$ for a less technical answer. They want to know how many walks are left. Will he make it

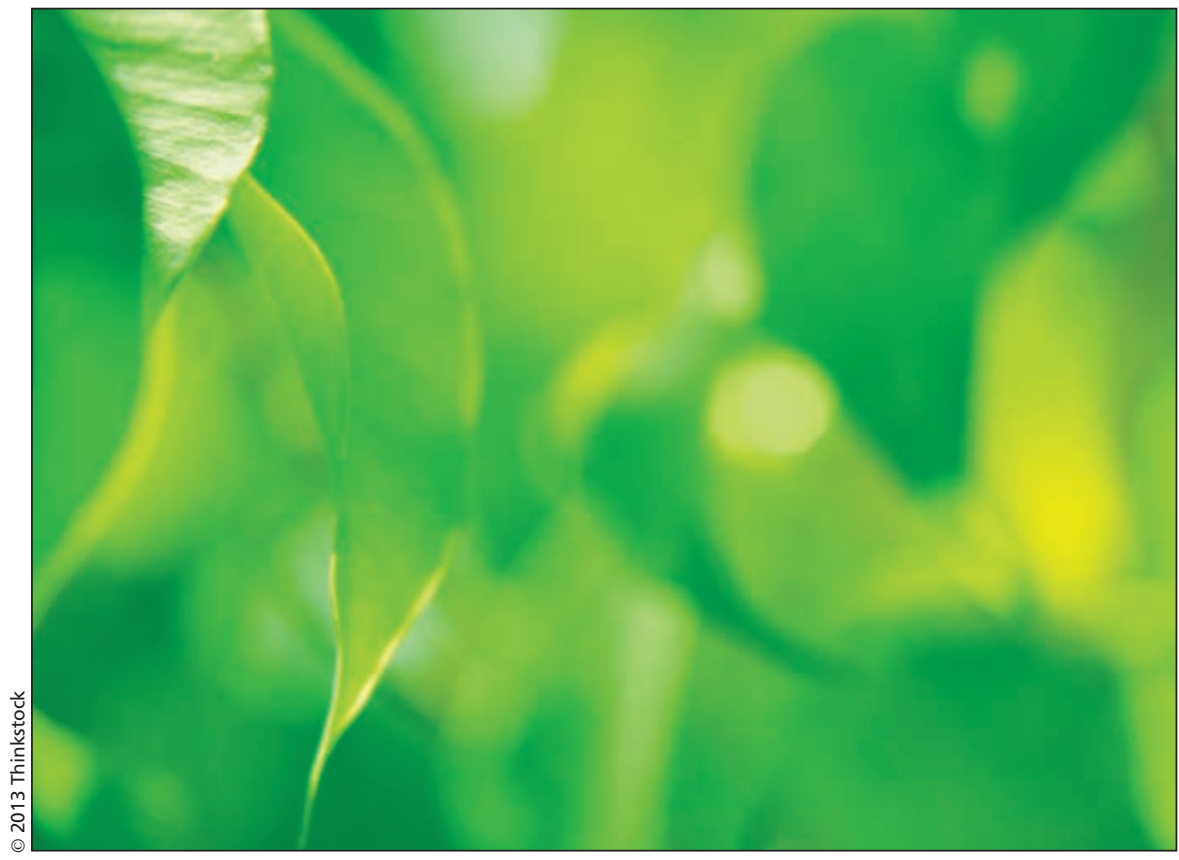

to spring? Plaintively, Dr. M spreads his hands in the air, palms up. His face says no. After a pause, he speaks,

"It is out of my hands."

And, in that moment, it feels like the humble finality of his answer is what they wanted. Their walks will now be to say goodbye, and the bike will stay parked in the garage until spring comes and he is gone.

$$
* * *
$$

Russian newlyweds are in the room along with the wife's mother and grandmother: three generations all at once, and a fourth to come.

The husband speaks softly and his hands are rough carpenter's hands. The lump in his side, long since flung to distant organs, now catches on the inside surface of his ribs when he tries to build houses, hammer nails, cut wood. The wife asks Dr. M:

"Is he in pain?"

Wordlessly, the wife paints a picture of him, inebriated opium-high, climb- ing ladders, swinging hammers and drawing saws.

They are young, and he wants to build until he drops. Someday, after he is gone, maybe she will be able to buy her own house with the money he makes in these last days.

She lets flutter out of her sleeve an ace she's been holding: a creased computer printout on the chaga mushroom, a Russian herbal remedy. As the wife fingers it, the grandmother whispers resignedly in the mother's ear. With nothing left to lose, the wife gambles that the mushroom is the one cure he has forgotten.

$\mathrm{He}$ sets the printout on the bed. $\mathrm{He}$ tells her softly about the things he knows and the things he doesn't know. She nods and cries silently while he passes an opioid prescription to the husband and tells him it is probably time to cut back on the dangerous stuff at work.

$$
* * *
$$

I tried to keep up with Dr. M as best I could. I let myself try to follow the 
conversations of mutagenesis without showing what I did know or pretending I knew more than I did. I allowed myself to share conciliatory smiles with people so sick I would never see them again, while remaining ghosted into the background. And I'll admit it. It emptied me out.

So empty all I could do was sleep. So empty I didn't realize I was empty until the next day. Even thinking now about how I felt yesterday makes me empty again. All the things I thought were good became wasteful. My own motives became wanton. The world became hostile and aggressive: a machine for breaking people. I was stripped bare. And that was only on my first day. But at least it was only my first day.

Witnessing death stare at you, all knowing, is a consumptive task. The time you've wasted, the things you've never done and the lies you've told yourself are all revealed. It is inescapably unnerving. I saw here that becoming a fully fleshed witness to the harsh omnipotence of death is a learned skill. I'll learn too how to hear from someone who is suffering, to give myself over to their story, and then to rebuild stronger, like a muscle.

$$
* * *
$$

Last night, while I slept, a man came to me with his cancer. He didn't know much about it, except that it scared him. I asked him to open his mouth, and I looked inside. It grew out of every junction. It grew out, green and treelike, from where his tongue met the bottom of his mouth. Down his throat and into his muscles and membranes and tissues. It had its own fleshy plant structure: all stems and waving green branches and seed pods. It was well rooted and greedy. It pushed its way into the spaces between the different parts of him. It made him its home. They lived together, the two of them.
They were joint animals. The same creature and, at the same time, not.

When I pulled my vision back out of him, he snapped his teeth shut like a gate and smiled at me. He was an average man again, indistinguishable from any other. But in his smile I knew we shared a secret. He harboured a growing life inside him, and he had shown it to me like a gift. He turned on his heel and left me standing there to sort out the pieces of myself and the world of his cancer with clumsy, well-intentioned hands.

\section{Tavis Apramian MA MS}

$\mathrm{MD} / \mathrm{PhD}$ matriculant

Schulich School of Medicine \& Dentistry

Western University

London, Ont.

All characters in this work are fictitious. Any resemblance to real persons, living or dead, is purely coincidental.

CMAJ 2013. DOI:10.1503/cmaj.122015

\section{POETRY}

\section{light}

quantum physics says that observation of light changes its behaviour

(particle or wave)

that reality changes with the watching

could it be light gets nervous?

panics during the investigation like a criminal found out

or a patient having their pressure checked (now hypertensive)

cortisol precipitating particles creating a billion watched lights and an infinity of little truths turned false

Andrew Smith BSc (Hons) MD

PGY2, Department of Psychiatry

University of Ottawa

Ottawa, Ont.

CMAJ 2013. DOI:10.1503/cmaj.131018

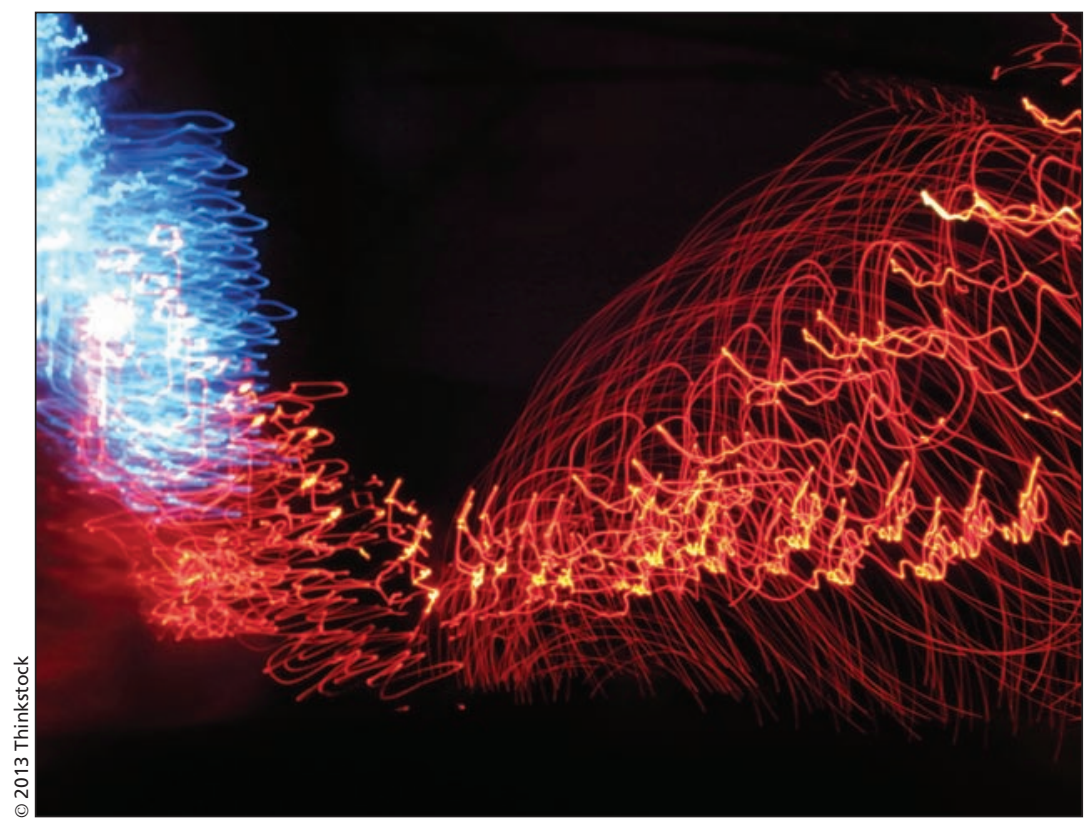

